\title{
Medical Students' Honesty Education Present Situation Investigation and Countermeasure Research
}

\author{
Chunling Liu ${ }^{1, a^{*}}$, Mingjun Zhao ${ }^{1, b}$ and Jianmin Shao ${ }^{1, c}$ \\ ${ }^{1}$ Luohe Medical College, Luohe 462002, China \\ a1172819778@qq.com, b996923191@qq.com, c313329111@qq.com
}

*The corresponding author

Keywords: Medical students; Good faith; Education research

\begin{abstract}
In this study to the medical students in our school as the research object, by the good faith the theme of the study, combined with the actual situation of the school,design evaluation questionnaire about college students' honesty, and carries on the questionnaire survey on college students' credit situation, understand the current situation of college students' honesty and credibility, from college students themselves, families, schools, social four aspects to further analyse the causes of college students' honesty, according to the broken reason to find the countermeasures to solve the problem of college students' credibility, and improve the integrity of medical students.
\end{abstract}

\section{Introduction}

Good faith, is honest and trustworthy, and is a kind of personality quality, is the essence of humanistic quality, is our country has a long history of traditional virtue and the spiritual pursuit of traditional culture, is also must abide by the basic moral quality of people.Medical students as a special group in society, determines the country's future and destiny, if integrity problems, not only conducive to the healthy growth of college students, but also conducive to the formation of good style of study and school spirit, is not conducive to the establishment of good faith society.

Yan $\mathrm{Li}^{[1]}$, Zhenmei $\mathrm{Yu}{ }^{[2]}$ respectively from different sides pointed out that the lack of sincerity college students mainly includes the external factors and internal factors, to strengthen medical students' honesty education, build medical students' integrity education system to improve college students' credit quality has important practical significance.

\section{The Research Object and Methods}

The questionnaire on the present situation of the college students' honesty, questionnaire survey for oral medicine, clinical medicine, nursing school students,

Involves problems mainly for tuition fees in arrears, the loan not also, exam cheating, plagiarism, resume the adulteration, employment default, poor students identity fraud, help a bit in class to ask for leave, lying, and other various aspects,Is individual choice and adoption of multiple-choice questions in two ways. A random sample of 1500 students, questionnaires and individual students, questionnaires out of 1500, among them 1460 effective questionnaires were taken back, effective questionnaire share of $97.3 \%$.

\section{Medical Students Integrity Analysis of the Status of the Investigation}

The Basic Situation of Medical Students' Honesty. From the results of the survey, college students is generally believed: Most college students are honest. Universal is the importance of college students with good faith, $93.5 \%$ of college students think that honesty is very important, is how the basic moral, is also one of the main factors of interpersonal communication. None of the people think that good faith is not important, it is of little use in interpersonal communication.Medical students integrity overall is good, but is affected by the social various aspects, the credibility of college students and also is facing a severe test, in all honesty 
phenomenon of study and life there are a lot of.

Problems of Contemporary College Students' Honesty. During the Period of School the Phenomenon of Lack of Good Faith. Cheating in the exam is one of the common phenomenon, the have an exam there is cheating, Shiying $\mathrm{Xu}{ }^{[3]}$ and Qiumin Ren ${ }^{[4]}$ survey found that college students also exists the phenomenon of cheating in the exam. As a result, schools are formulated the strict examination rules and regulations and corresponding punishment, but there are still some students take risks, frequent cheating in the exam. As a result, schools are formulated the strict examination rules and regulations and corresponding punishment, but there are still some students take risks, frequent cheating in the exam.Such as mobile phones, the Internet becomes a part of life, the means of cheating in the exam from the traditional cheat sheet, with development of using mobile phones to send information, such as more their stead.Survey found that nearly half of the students never had a cheating in the exam, a third of the students cheat once in a while, a few students have always cheating.

Cover the Hiatus Phenomenon. Nowadays, college students' employment pressure is more and more big, the graduates to win the favor of unit of choose and employ persons, make oneself can get a satisfactory job, appropriate to beautify decorate their CVS.Counterfeit marks in the CVS, increase the school training experience, the letter of self recommendation is filled with a lot of grandiose rhetoric.There are some students in the process of choosing a default and breach of promise, they first sign employment agreement with recruiters, after being hired, but glibly alibi, job-hopping to tear up the contract, in defiance of the employment contract, no good faith.

\section{The Lack of Sincerity of Contemporary College Students}

Social Aspects. College students in the spring tide of market economy, in order to get their own interests by hook or by crook, could be the good faith crisis will naturally formed. University is not a vacuum, the lack of honesty in society phenomenon will inevitably affect the campus, make some college students are not adversely affected. Anling $\mathrm{Ji}^{[5]}$ in the present college students' honesty and education, the article puts forward countermeasures to solve college students' honesty education countermeasures:Social credit system construction is a key link in the process of integrity education, the social credit system is not perfect in our country, credit supervision mechanism is not sound, lack of effective evaluation and punishment mechanism for integrity behavior, and trustworthy people do not have proper rewards, and not honest person also can not get due punishment.

Schools. School has always been imparting knowledge as the focus of the teaching work, but not enough emphasis on good faith education, to carry out the honesty education activity is not much and not thorough, part of the education workers and students' awareness of good faith degree is insufficient.Simply ignored the honesty education and university teachers, school teachers only pay attention to teaching and ignored the education.In teaching by simply preach, theory, it is difficult to let students purely theoretical knowledge into spiritual belief, is difficult to make college students form good faith consciousness. And lack of integrity constraints and evaluation mechanism, lack of credibility penalties is not enough, also does not have personal integrity status for college students in the supervision and evaluation, rewards and punishment policy.

Family and Their Own Factors. Family is the child grow the first school, parents are the first teacher of children. Parents' words and deeds to the child the influence is subtle, is also very large. And some of the parents to the child's education focus on children's academic performance, and not enough attention to good faith, the moral education. The present college students are mostly only children, psychological heavier self-centered, think others for their own pay. So the family lack of integrity education is also one of the reasons why college students lose honesty and credit.

\section{To Strengthen College Students' Honesty Education Countermeasures}

Give full play to the family, school and social function of integrity education, college students' honesty education is a systematic project, which can not be simply summed up in one aspect of the responsibility, should be the responsibility of the family, school and society to share. These three 
aspects interact with each other, mutual combination, to build a trinity of integrity education network, make the good faith education students growing roots of every corner. Sumei $\operatorname{Ren}^{[6]}$ present situation and countermeasure on college students' honesty education to explore that focus on education for young college students honesty education and regular education, the combination of daily education combined with multi-channel education, combining students' self-discipline and heteronomy, and to establish a good environment for small and big atmosphere with the combination of strategies to strengthen college students' honesty.

First of all, the good faith education must attach importance to family. Parents should set a good example, everywhere pays attention to good faith, parents need to be able to do this, first before requiring children to do not only focus on their children's academic performance, and ignore the cultivation of moral integrity.Secondly, colleges and universities is the cradle of college students' growth, but also college students leave home to live independently. Therefore, the construction of college atmosphere of honesty in college students form the habit of good faith is very important.Can let students sign a guarantee of good faith, Chunhua $\mathrm{Li}^{[7]}$ point out that students can establish the good faith business records, etc., to student's honest and dishonest ACTS should be recorded in the archives.Finally, give play to the social role of honesty education. Students accept the good faith the ultimate goal of education is to foothold in the society. In today's society has gradually pay attention to a person of integrity.Unit of choose and employ persons are gradually in talent selection of good faith on the first condition of recruitment, the second is focus on students' various abilities and during the period of school grades. Must treat honesty education throughout the course of life education, not only stay in the stage of school education.

Medical students this kind of special groups, as in the future in the field of medical workers and managers, and undertakes to heal the wounded and rescue the dying, to promote human health mission, their integrity character status determines the results of their behavior and behavior, this is directly related to people's physical and mental health and life safety.Therefore, strengthen the integrity education of medical students is the foundation of moral construction of medical industry, and also for the maintenance of the health care industry.

\section{References}

[1] Yan Li. The causes and countermeasures of college students' honesty [J]. Chinese science, 2014, (4): 104. (in Chinese)

[2] Zhenmei Yu. The lack of contemporary college students' honesty and ethics and education countermeasures [J]. Journal of education and profession, 2010, (32): 72-73. (in Chinese)

[3] Shiying Xu, Mengqian Hou, Lidan Wang. College students' honesty education present situation investigation and thinking - based on the survey data of colleges and universities in jiangsu province [J]. Journal of intelligence, 2015, (2): 98. (in Chinese)

[4] Qiumin Ren. From the education college students cheating in the exam to see honesty and credit status quo- cet exams, for example [J]. Journal of hubei admission examination, 2012, (2): 62-64. (in Chinese)

[5] Anling Ji. The present college students' honesty and education countermeasure analysis [J]. Journal of baoji college of arts and science (social science edition), 2014 (6): 149-151. (in Chinese)

[6] Sumei Ren. College students' honesty education present situation and countermeasures of exploring [J]. Journal of BBS industry and science and technology, 2014, 13 (20): 158-159. (in Chinese)

[7] Chunhua Li. An empirical analysis of the college students' honesty education and countermeasures thinking [J]. Journal of continuing education research, 2015, (1): 76-77. (in Chinese) 
